\title{
Larval development of the rock shrimp Rhynchocinetes typus Milne Edwards, 1937 (Decapoda, Caridea) reared in the laboratory
}

\author{
Desarrollo larval del camarón de roca Rhynchocinetes typus Milne Edwards, 1937 \\ (Decapoda, Caridea) cultivados en laboratorio \\ ENRIQUE DUPRÉ ${ }^{*}$, LUIS FLORES $^{1} \&$ SERGIO PALMA $^{2}$ \\ ${ }^{1}$ Departamento de Biología Marina, Facultad de Ciencias del Mar, Universidad Católica del Norte, Casilla117 \\ Coquimbo,Chile; edupre@ucn.cl \\ ${ }^{2}$ Escuela de Ciencias del Mar, Pontificia Universidad Católica de Valparaíso, Valparaíso, Chile \\ *e-mail for correspondence: edupre@ucn.cl
}

\begin{abstract}
The first description of the larval stages of a representative of the family Rhynchocinetidae from the southeastern Pacific coast of South America is presented. Larvae of the rock shrimp Rhynchocinetes typus, from rocky subtidal environment of the Chile-Peru coast were reared in the laboratory at $22{ }^{\circ} \mathrm{C}$, salinity 32 and feeding with Artemia franciscana. Seven zoeal stages, which occur through 10 successive moults, are described and illustrated in detail. Morphological comparison made between $R$. typus and other congeneric and related species belonging to Rhynchocinetid showed the main characteristic for the diagnosis of zoeal stages are: (a) the pereiopods appear in the third stage, (b) the exopod of the antennae have six segments, and (c) no pleopods were found on the seven stages. The main difference with related species was the presence of three lacinia in the right mandible at stage VII.
\end{abstract}

Key words: larval development, shrimp, Rhynchocinetes, Caridea, Chile.

\section{RESUMEN}

Se describe por primera vez el desarrollo larval de un representante de la familia Rhynchocinetidae en aguas del Pacífico suroriental. Las larvas de camarón de roca Rhynchocinetes typus Milne Edwards, 1937 que habita en el submareal rocoso de la costa de Chile-Perú, se cultivaron en laboratorio a $22{ }^{\circ} \mathrm{C}$, con salinidad de 32 y se alimentaron con Artemia franciscana. Se determinaron siete estados de zoea que ocurren a través de 10 mudas sucesivas. Cada uno de los estados se describió e ilustró detalladamente. La comparación morfológica con otras especies congenéricas y otras especies de la familia Rhynchocinetidae indicó que las principales características distintivas de los estados de zoea fueron: (a) el primer par de pereiópodos aparece en la zoea III, (b) el exopodito de la antena presenta seis segmentos, y (c) no se observaron pleópodos en ninguno de los siete estados descritos. La principal característica que diferencia la zoea de $R$. typus de las demás especies es la presencia de tres lacinias en la mandíbula derecha en el estado VII.

Palabras clave: desarrollo larval, camarón, Caridea, Rhynchocinetes, Chile.

\section{INTRODUCTION}

Many of the biological studies related to the marine meroplankton, in Chile, have been affected by the difficulty in the recognition of the larval diversity at specific level (Palma 1976, 1980, Mujica 1993, Albornoz \& Wehrtmann 1997, Barría et al. 2006) because the information of larval biology at the species level is very scarce for decapod crustaceans from the southeastern Pacific Ocean, particularly regarding the Chile-Peru and Magellanic zoogeographic provinces (Boschi 2000). In addition, Wehrtmann \& Báez (1997) pointed out that larval development of only $13.4 \%$ of the Chilean crustacean decapods have already been described.

According to Retamal (2000) the caridean species from Chile include 46 species that belong to 13 families, however the complete larval development of only three species have been described (Báez 1997). At present the 
only information about the larval development of the Rhynchocinetidae from Chile is the description of the first zoea stage of the $R$. typus (Albornoz \& Wehrtmann 1997). In the meroplankton of the central coast of Chile, the caridean larvae are found year-round, but they are most abundant during spring, particularly in October (Palma 1976, 1980).

The family Rhynchocinetidae encompasses the Caridea Infraorder and includes eight species distributed into the genera Cinertorhynchus and Rhynchocinetes. Cinertorhynchus include $C$. hendersoni Kemp 1925, C. rigens Burkenroad 1939, C. striatus (Nomura \& Hayashi 1992) and C. manningi Okuno 1996, while the Rhynchocinetes genera include $R$. typus Milne-Edwards 1833, $R$. balssi Gordon 1936, $R$. rigens Gordon 1936, $R$. rugulosus Stimpson 1897, R. uritani Kubo 1942 and R. conspiciocellus Okuno \& Takeda 1992.

Only two species of the family Rhynchocinetidae were found in Chile: Rhynchocinetes balssi has been reported on Robinson Crusoe Island and Easter Island (Retamal 2000) and R. typus distributed along the west coast of South America from Lobos de Afuera, Perú $\left(6^{\circ} 30^{\prime}\right.$ S) to San Vicente bay, Chile (33³0' S) (Bahamonde \& López 1967, Retamal 2000). This species inhabits rocky bottoms, preferring crevices and caves from the upper subtidal (Vásquez \& Castilla 1982) to 30 m depth (Miranda \& Kong 1970).

The rock shrimp Rhynchocinetes typus, a commercial species in some regions of Chile, constitute an outstanding component of a broad spectrum of subtidal hard-bottom communities (Correa \& Thiel 2003). This species has a not synchronized reproductive cycle, which generates a continuous reproduction along the year (Correa \& Thiel 2003). Some authors suggested that rock shrimp migrate to shallow waters (Vásquez \& Castilla 1982) when they reproduce however Correa \& Thiel (2003) after the examination of the population lived year-round suggested that reproductive migration are of minor importance or not migrates to reproduces as other caridean crustaceans.

The occurrence of 10 larval stages was reported for $R$. ringens from the Gulf of Aqaba (Gurney 1942, Seridji 1986), 11 stages for Cinetorhynchus striatus (Maihara \& Kyoya 2001a), C. hendersoni (Maihara \& Kyoya 2001b), 10 stages for $R$. uritani (Maihara 2002) and 11 stages for $R$. conspiciocellus (Motoba \& Shokita 1998).

The purpose of this study is to describe in detail seven stage of larval development of the rock shrimp $R$. typus reared in laboratory conditions and to compare the morphology of these southeastern Pacific species with other species encompasses to the same family.

\section{MATERIAL AND METHODS}

Ovigerous females of Rhynchocinetes typus were collected from La Herradura Bay, Coquimbo, Chile, and maintained in a $50 \mathrm{~L}$ aquarium with a continuous flow of bay water $\left(22 \pm 1.5^{\circ} \mathrm{C}\right)$ and feeding ad libitum with soft tissue from clams (Gari solida). Females carrying stage-10 embryos (Dupré et al. 1992), verified by microscopic examination, were placed into $20 \mathrm{~L}$ aquaria; with semi-submerged $450 \mu \mathrm{m}$ mesh sieves attached to their outflow pipes for recovery of recently hatched larvae.

Recently hatched larvae were cultured in $250 \mathrm{~mL}$ plastic bowl each holding $150 \mathrm{~mL}$ of filtered seawater. Each plastic container was placed in a styrofoam tray employed as a constant temperature water bath; the incubation temperature was regulated at $22 \pm 0.5^{\circ} \mathrm{C}$ with a Jaeger $1.8 \mathrm{~A}$ thermoregulator. A maximum of 100 bowls could be maintained in this system, with each bowl containing three recently hatched larvae. Seawater for culture bowl was filtered to $50 \mu \mathrm{m}$ pore size and UV irradiated; the temperature remained al $22 \pm 0.5{ }^{\circ} \mathrm{C}$ at a salinity of 32 with a natural photoperiod. The larvae were fed ad libitum with recently hatched Artemia franciscana nauplii.

Larvae were daily transferred to fresh containers using $3 \mathrm{~mm}$ Pasteur pipettes. Recently moulted larvae as well as exuviae were fixed in $3 \%$ glutaraldehyde in seawater solution for subsequent observation by light microscopy. Dead larvae were not replaced.

Twenty larvae of each larval stage were described following the procedures of Williamson (1969) and Schultze \& Anger (1997). In cases where a larva moulted but did not undergo a change of stage, the larva retained the name of the preceding stage, noting number of times this type of moult was 
repeated. The arbitrary term "instar" was used to denote each intermoult period, independent of the stage of development (Hartnoll 1982, Schultze \& Anger 1997). The terminology of Walsh (1993) was used for describing larval appendages.

Dissections were carried out with entomological needle in a drop of gliceraldehyde (Walsh 1993) under a Wild stereoscopic microscope and drawings with a camara lucida at $100 \mathrm{X}$ and $400 \mathrm{X}$. The size proportion of the segments was numbered from the proximal to the distal position (Walsh 1993).

\section{RESULTS}

Larval development of this species occurred over a period of 33 days at $22 \pm 0.5{ }^{\circ} \mathrm{C}$. Seven morphological stages were observed through seven successive individual moults. Zoea VI underwent one additional (instar) moult and zoea VII underwent two instar moults, through which growth occurred without morphological changes. Thus a total of 10 moults were observed over the entire developmental process. The cephalothoracic length of these larvae varied between $698 \pm 18.5 \mu \mathrm{m}$ at zoea I $(\mathrm{n}=300)$ and $1.280 \pm 15.9 \mu \mathrm{m}$ at zoea VII $(\mathrm{n}=$ 121). Zoea VII occurred 25 days post hatching $(\mathrm{n}=138)$. The longest intermoult periods occurred in the first three stages (zoea I-III), with the longer average intermoult period in the zoea II which lasted $3.95 \pm 0.39$ days $(\mathrm{n}=248)$. The remaining stages had average intermoult periods of between 2.8 and 3.1 days (average $n$ $=160$ ).

Metamorphosed larvae were not observed in any of the cultures after reaching the zoea VII, at this stage the individuals continued to moult and grow without producing morphological changes.

\section{Zoea I}

Carapace. The rostral spine is slightly curved downward. The eyes are sessile, and the pterigostomial spine is small and smooth.

Telson (Fig. 1A). Is triangular and bilobed, with seven plumose setae inserted in each lobe. The distal border is covered with small spines. No uropods are observed.
Antenna (Fig. 1B). The scaphocerite is divided into six segments in a proportion of 6 : 1: 1: 1: 1: 0.5 with 12 plumose setae arranged $3,2,1,1,1,4$. The antennal peduncle has a small serrate spine on its internal border. The interior flagellum is supported by a distal spine. The flagellum is elongated and plumose, having a length of $2 X$ the scaphocerite.

Antennule (Fig. 1C). The antennal peduncle is unsegmented, robust, and is $2.5 \mathrm{X}$ the length of the exterior flagellum. The interior flagellum is in the form of a long plumose seta, and is $4.5 \mathrm{X}$ longer than the exterior flagellum. The exterior flagellum is small and robust, with three naked aesthetes and a plumose seta in a distal position.

Mandible (Fig. 1D-E). The left molar process has 3-4 rows of small, marginal denticles, and two robust tridentate teeth between the molar and incisor process; the endopod palp (lacinia movilis) is absent. The incisor has three terminal teeth and one subterminal tooth. The right molar process has 3-4 rows of small, marginal denticles. The endopod palp (lacinia movilis) is serrated on one side. The incisor process has four sharp teeth.

Maxilla (Fig. 1F). The scaphognathite has five plumose setae on its external margin. An unsegmented endopodite is formed of five lobes, with nine plumose setae on its external margin arranged $3,2,1,1,2$. The basal endite has proximal and distal lobes, each bearing three plumose setae. The coxal endite has a distal lobe with four plumose setae, and a proximal lobe bearing nine plumose setae.

Maxillule (Fig. 1G). The exopodite has two plumose setae. The endopodite has three plumose terminal setae and two subterminal plumose setae. The basal endite has five sharp, naked spines, and the coxal endite six curved, naked spines.

First maxilliped (Fig. 1H). The exopodite is elongated and is $1.5 \mathrm{X}$ the length of the endopodite, and is formed of two segments. The distal segment is very small with two plumose distal setae equal in size, and the proximal segment is naked. The endopodite is divided into four segments in the proportion 1 : $1: 1.5: 1$ with nine plumose setae arranged 2, $1,2,3+1$. The basipodite and coxopodite bear a total of 13 plumose setae.

Second maxilliped (Fig. 1J). The exopodite is elongated and is $2 \mathrm{X}$ the length of the 
endopodite, and formed of two segments; the distal segment is very small with three plumose distal setae. The endopodite is formed of four segments in the proportion $1: 1: 1.5: 1$ and has 11 plumose setae distributed in a $3,1,2,3$ +1 formula. The basipodite and coxopodite bear five to seven plumose setae.

Third maxilliped (Fig. 1I). The exopodite is $1.5 \mathrm{X}$ the length of the endopodite and is divided into three segments. The basal segment is $7 \mathrm{X}$ the second segment and has two plumose setae on its terminal border; the distal segment is small, with three plumose terminal setae. The endopodite is divided into four segments in the proportion $1.5: 1.5: 2: 1$ with eight plumose setae arranged 1, 1, 3, 3. The basipodite and coxopodite are naked.

Pereiopods. Absent.

Abdomen. Six somites, with the sixth segment fused to the telson.

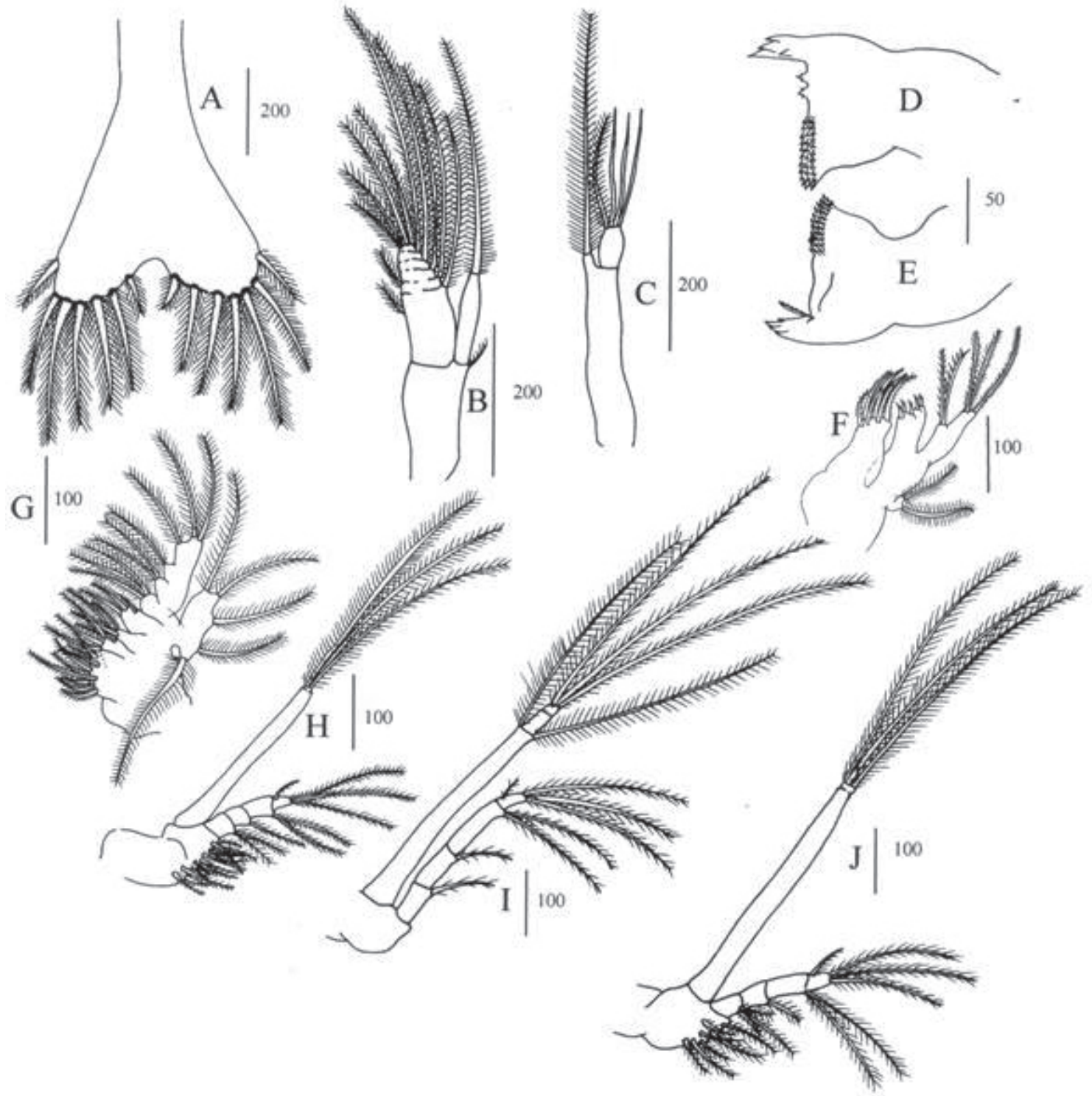

Fig. 1: Rhynchocinetes typus, zoea I. (A) telson, (B) antenna, (C) antennule, (D) left mandible, (E) right mandible, $(\mathrm{F})$ maxillule, $(\mathrm{G})$ maxilla, $(\mathrm{H})$ first maxilliped, (J) second maxilliped, (I) third maxilliped. Scales in $\mu \mathrm{m}$.

Rhynchocinetes typus, zoea I. (A) telson, (B) antena, (C) anténula, (D) mandíbula izquierda, (E) mandíbula derecha, (F) maxílula, $(\mathrm{G})$ maxila, $(\mathrm{H})$ primer maxilípedo, $(\mathrm{J})$ segundo maxilípedo, (I) tercer maxilípedo. Escalas en $\mu \mathrm{m}$. 


\section{Zoea II}

Carapace and abdomen. Simlar to the preceding stage. The eyes are now pedunculate.

Telson (Fig. 2A). This is separated from the abdomen,

Antenna (Fig. 2B). Unchanged.

Antennule (Fig. 2C). The antennular peduncle is non-segmented and shows two plumose setae on its sub-distal border. The exterior flagellum is robust, with three aesthetes on its distal border plus one plumose seta. The interior flagellum is in the form of a long plumose seta.

Mandible (Fig. 2D-E). Unchanged.

Maxilla (Fig. 2F). The scaphognathite, endopodite, and basal endite are similar to zoea I. The coxal endite has four plumose setae on the distal lobule, and 10-11 plumose setae on the proximal lobule.

Maxillule (Fig. 2G). The exopodite and endopodite are similar to zoea I. The basal endite has six spines, and the coxal endite bears seven plumose setae.

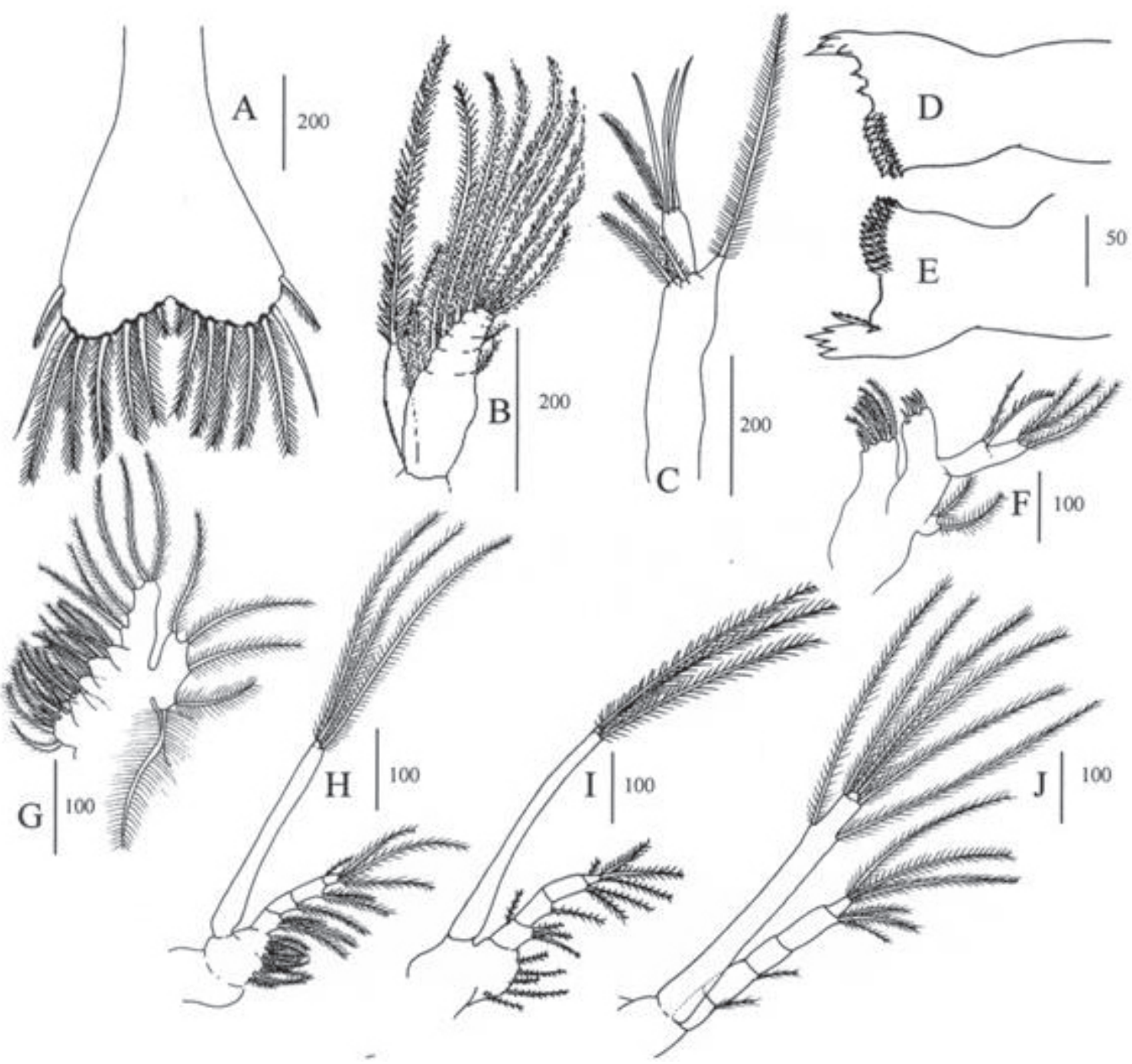

Fig. 2: Rhynchocinetes typus, zoea II. (A) telson, (B) antenna, (C) antennule, (D) left mandible, (E) right mandible, $(\mathrm{F})$ maxillule, $(\mathrm{G})$ maxilla, $(\mathrm{H})$ first maxilliped, $(\mathrm{I})$ second maxilliped, $(\mathrm{J})$ third maxilliped. Scales in $\mu \mathrm{m}$.

Rhynchocinetes typus, zoea II. (A) telson, (B) antena, (C) anténula, (D) mandíbula izquierda, (E) mandíbula derecha, (F) maxílule, $(\mathrm{G})$ maxila, $(\mathrm{H})$ primer maxilípedo, (I) segundo maxilípedo, (J) tercer maxilípedo. Escalas en $\mu \mathrm{m}$. 
First maxilliped (Fig. 2H). The endopodite and exopodite are similar to zoea I. The basipodite and coxopodite bear 11 and five setose spines, respectively.

Second and third maxillipeds (Figs. 2I-J). Unchanged.

Pereiopods. Rudimentary endopodite and exopodite, equal in size.

\section{Zoea III}

Telson (Fig. 3A). Its form and number of spines per lobule are similar to the preceding stage. Its uropods are well defined with six plumose setae on the distal border of the exopodite. The endopodite bears two terminal plumose setae.
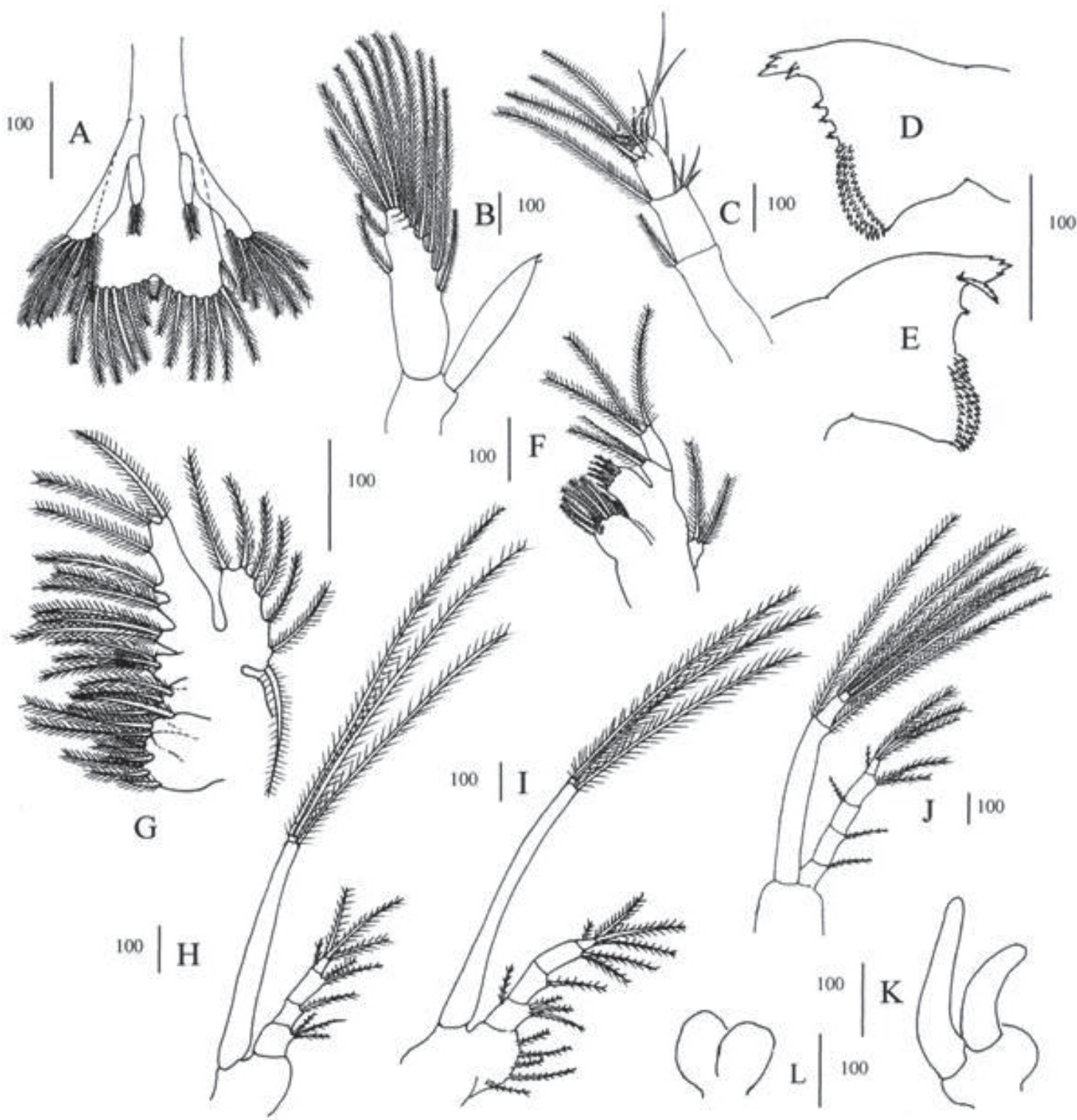

Fig. 3: Rhynchocinetes typus, zoea III. (A) telson, (B) antenna, (C) antennule, (D) left mandible, (E) right mandible, $(\mathrm{F})$ maxillule, $(\mathrm{G})$ maxilla, $(\mathrm{H})$ first maxilliped, (I) second maxilliped, (J) third maxilliped, (K) first pereiopod, (L) second pereiopod. Scales in $\mu \mathrm{m}$.

Rhynchocinetes typus, zoea III. (A) telson, (B) antena, (C) anténula, (D) mandíbula izquierda, (E) mandíbula derecha, (F) maxílule, (G) maxila, (H) primer maxilípedo, (I) segundo maxilípedo, (J) tercer maxilípedo, (K) primer pereiópodo (L) segundo pereiópodo. Escalas en $\mu \mathrm{m}$. 
Antenna (Fig. 3B). The scaphocerite is $1.3 \mathrm{X}$ the length of the flagellum, and formed of four segments in an $8,1,1,4$ formula. The flagellum is non-segmented with a distal, naked spine. The peduncle terminates in a spine below the flagellum.

Antennule (Fig. 3C). The antennular peduncle is divided into three segments in a proportion of $3: 1: 1$. The first segment bears a lateral plumose spine. The second segment bears a long plumose seta on its internal laterodistal border, and four small, naked setae on its external latero-distal border. The mid-portion of the distal segment bears three plumose setae, two of which are long and thickened; its subterminal border bears five plumose setae which are small and transparent. The interior flagellum is in the form of a long plumose seta, and the exterior flagellum bears two aesthetes with two plumose setae on its distal border.

Mandibles (Fig. 3D-E). The left process is similar to zoea I, except for the appearance of another sub-distal denticle on the incisor. The right process is similar to zoea I, except for the appearance of a serrated tooth between the molar and incisor.

Maxilla (Fig. 3F). The scaphognathite bears seven plumose setae on its exterior margin. The endopodite and basal endite are similar to zoea I; the coxal endite bears four plumose setae on the distal lobule, and six plumose setae on the proximal lobule.

Maxillule (Fig. 3G). The exopodite is bisegmented, with two plumose distal setae on each segment. The endopodite is similar to zoea I. The basal endite bears eight spines, and the coxal endite bears 7-8 plumose setae.

First maxilliped (Fig. 3H). The endopodite bears three plumose setae on the proximal segment and four plumose distal setae and one lateral plumose seta on the distal segment. The endopodite bears three plumose setae on the proximal segment, and four plumose distal setae and one lateral plumose seta on the distal segment. The basipodite and coxopodite bear a total of 15 plumose setae.

Second maxilliped (Fig. 3I). The endopodite is formed of four segments in the proportion 1 : $1: 1.5: 0.5$ with 12 plumose seta in a $3+1,1$, $2,4+1$ formula. The basipodite bears five plumose setae, and the coxopodite is naked.

Third maxilliped (Fig. 3J). The exopodite is $1.3 \mathrm{X}$ the length of the endopodite, and divided into three segments in the proportion 5: 1: 0.5 , with six plumose setae distributed distally in a 2, 2, 2 formula. The endopodite is divided into five segments in the proportion $1: 2: 1.5: 2$ : 1 , with nine plumose setae in a $1,1,1,2,3+1$ formula. The basipodite bears one spine, and the coxopodite is naked.

First pereiopod (Fig. 3K). The exopodite and endopodite are non-segmented, with the exopodite 2 time the length of the exopodite.

Second pereiopod. Shows rudimentary exopodite and endopodite.

\section{Zoea IV}

Telson (Fig. 4A). Is similar to the preceding stage. The uropods have an exopodite with 12 plumose setae and an endopodite with seven plumose setae. There is a robust central spine on the terminal border of the sixth abdominal segment.

Antenna (Fig. 4B). The scaphocerite is unsegmented and scaly, and is similar in size to the flagellum, terminating with a small spine on its distal interior border. The exterior border bears 16 plumose, elongated setae. The flagellum is bisegmented. The distal segment is $5 \mathrm{X}$ the proximal segment, and bears a small terminal spine.

Antennule (Fig. 4C). The antennular peduncle is divided into three segments in a proportion of 3 $: 1: 1$. The proximal segment bears four plumose spines on its exterior latero-distal border, and on its lateral interior border a naked median spine and a distal, long, plumose seta. The second segment bears 3-4 naked setae on the external latero-distal border, and one long plumose seta on the internal latero-distal border. The distal segment bears four thick, centrally located plumose setae and one naked lateral seta. There are five naked, sub-terminal transparent setae and interior and exterior flagellae similar to zoea III.

Mandible (Fig. 4D-E). The left and right processes are similar to zoea III, except for the appearance of the lacinia movilis as two serrate structures on the right mandible.

Maxilla (Fig. 4F). The scaphognathite is unsegmented, with eight plumose setae. The endopodite is similar to zoea I. The distal and proximal lobes of the endite each bear four plumose setae. The coxal endite has a distal lobe with four plumose setae and a proximal lobe with $10-13$ plumose setae. 

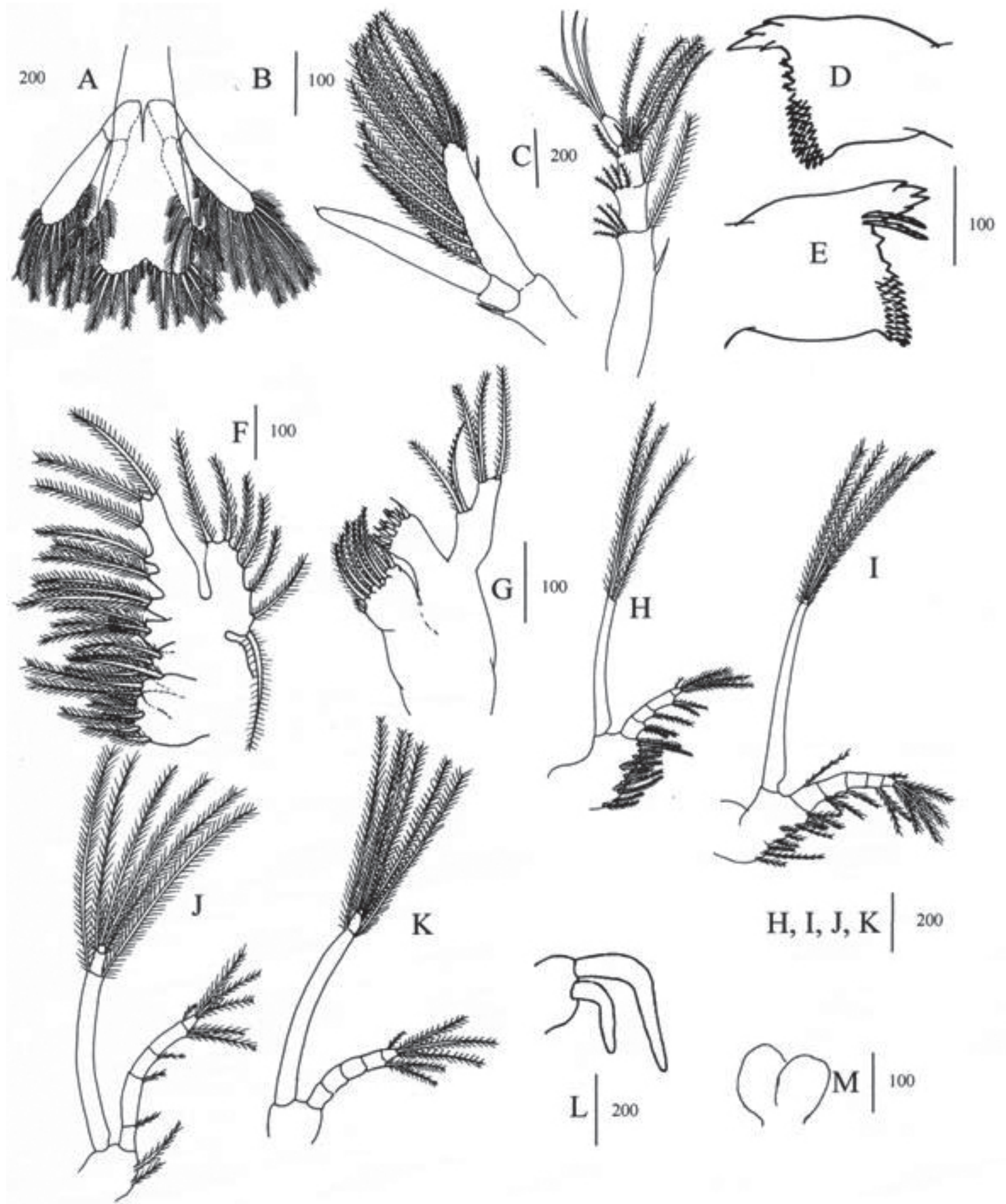

$$
\mathrm{H}, \mathrm{I}, \mathrm{J}, \mathrm{K} \mid 200
$$

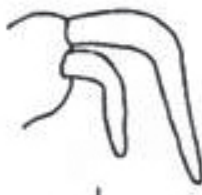

L 200

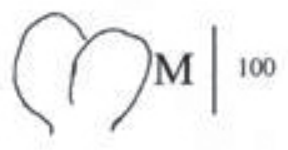

Fig. 4: Rhynchocinetes typus, zoea IV. (A) telson, (B) antenna, (C) antennule, (D) left mandible, (E) right mandible, $(\mathrm{F})$ maxilla, $(\mathrm{G})$ maxillule, $(\mathrm{H})$ first maxilliped, (I) second maxilliped, (J) third maxilliped, (K) first pereiopod, (L) second pereiopod, (M) third pereiopod. Scales in $\mu \mathrm{m}$.

Rhynchocinetes typus, zoea IV. (A) telson, (B) antena, (C) anténula, (D) mandíbula izquierda, (E) mandíbula derecha, (F) maxílule, $(\mathrm{G})$ maxila, $(\mathrm{H})$ primer maxilípedo, (I) segundo maxilípedo, (J) tercer maxilípedo, (K) primer pereiópodo (L) segundo pereiópodo, (M) tercer pereiópodo. Escalas en $\mu \mathrm{m}$. 
Maxillule (Fig. 4G). No exopodite is observed. The endopodite are similar to zoea I. The basal endite has three naked, and six subdentate spines. The coxal endite bears nine plumose setae.

First maxilliped (Fig. 4H). Unchanged.

Second maxilliped (Fig. 4I). The exopodite is similar to zoea I. The endopodite is divided into five segments. The basipodite and coxopodite bear 10 plumose setae.

Third maxilliped (Fig. 4J). Unchanged.

First pereiopod (Fig. 4K). The length of exopodite is 3 time the endopodite and is formed of three segments in the proportion 10 : $1: 0.25$, and with six plumose setae in a 2 , $2,2+1$ formula. The endopodite has five segments in the proportion $1: 1: 1: 1: 0.5$ and with six plumose setae in a $0,0,0,2,3+$ 1 formula. The basipodite and coxopodite are naked.

Second and third pereiopods (Fig. 4L-M). Unchanged.

\section{Zoea $V$}

Telson (Fig. 5A). Is rectangular in form; the external margin slightly bilobulate; with eight setose spines on each lobule. The uropods have an exopodite with 14-15 plumose setae on the internal border; the endopodite has 10 plumose setae on the internal border.

Antenna (Fig. 5B). The scaphocerite is similar to zoea IV. The flagellum is $2-5 \mathrm{X}$ the length of the scaphocerite and has 8-10 segments; the distal segment bears two naked terminal spines.

Antennule (Fig. 5C). Unchanged.

Mandible (Fig. 5D-E). The left mandible remains unchanged; the right mandible shows a new distal tooth on the incisor process.

Maxilla (Fig. 5F). Both lobes of the basal endite and the distal lobe of the coxal endite bear five plumose setae.

Maxillule (Fig. 5G). Similar to zoea IV. No exopodite is observed.

First maxilliped (Fig. 5H). Basipodite and coxopodite bear a total of 16-19 plumose setae.

Second maxilliped (Fig. 5I). The exopodite is bisegmented and $2 \mathrm{X}$ the length of the endopodite; the distal segment is very small with two terminal plumose setae; the proximal segment has two distal setae and one lateral seta. The endopodite is divided into five segments in the proportion $1: 1.5: 1: 1: 0.5$ with 12 plumose setae distributed in a $3+1,1$, $0,2,4+1$ formula. The basipodite bears seven plumose spines.

Third maxilliped (Fig. 5J). The basipodite bears two naked setae.

Pereiopods (Fig. 5K-M). First pereiopod: the endopodite has a setal formula of 2, 1, 1, 2, $3+$ 1 ; the basipodite has one plumose seta and the coxopodite is naked. Second (Fig. 5L) and third pereiopods (Fig. 5M) unchanged.

\section{Zoea VI}

Carapace. The rostrum presents a sub-spine at the basal level, with the remainder similar to the preceding stage, and undergoes no further modification.

Telson (Fig. 6A). The exopodites of the uropods have 17-18 setae on the upper lateral and interior borders. The endopodite bears 1415 plumose setae.

Antenna (Fig. 6B). These have 18-19 plumose setae on the edge of the antennal scale.

Antennule (Fig. 6C). These are formed by three segments similar in proportion to those of zoea IV. The proximal segment has 4-6 setose spines and a large plumose seta on the distal border; at its mid-level occur one naked seta plus two spines, one setose and the other naked and robust. The middle segment bears five small plumose setae on the latero-distal border, plus one large plumose seta. The distal segment is similar to that of zoea IV. The interior and exterior flagellae are similar to zoea III.

Mandible (Fig. 6D-E). Unchanged.

Maxilla (Fig. 6F). The scaphognathite bears 12-13 plumose setae on its external border.

Maxillule (Fig. 6G). Shows the presence of eight subdentate and three naked spines on the basal endite; the coxal endite bears 12 plumose setae.

First maxilliped (Fig. 6H). The exopodite is bisegmented with five plumose setae distributed in the formula $2+1.2$; the distal segment is very small.

Second and third maxillipeds (Figs. 6I-J). Unchanged.

First, second and third pereiopods (Fig. 6KM). Unchanged

Four pereiopod (Fig. 6N). It shows rudimentary exopodite and endopodite. 


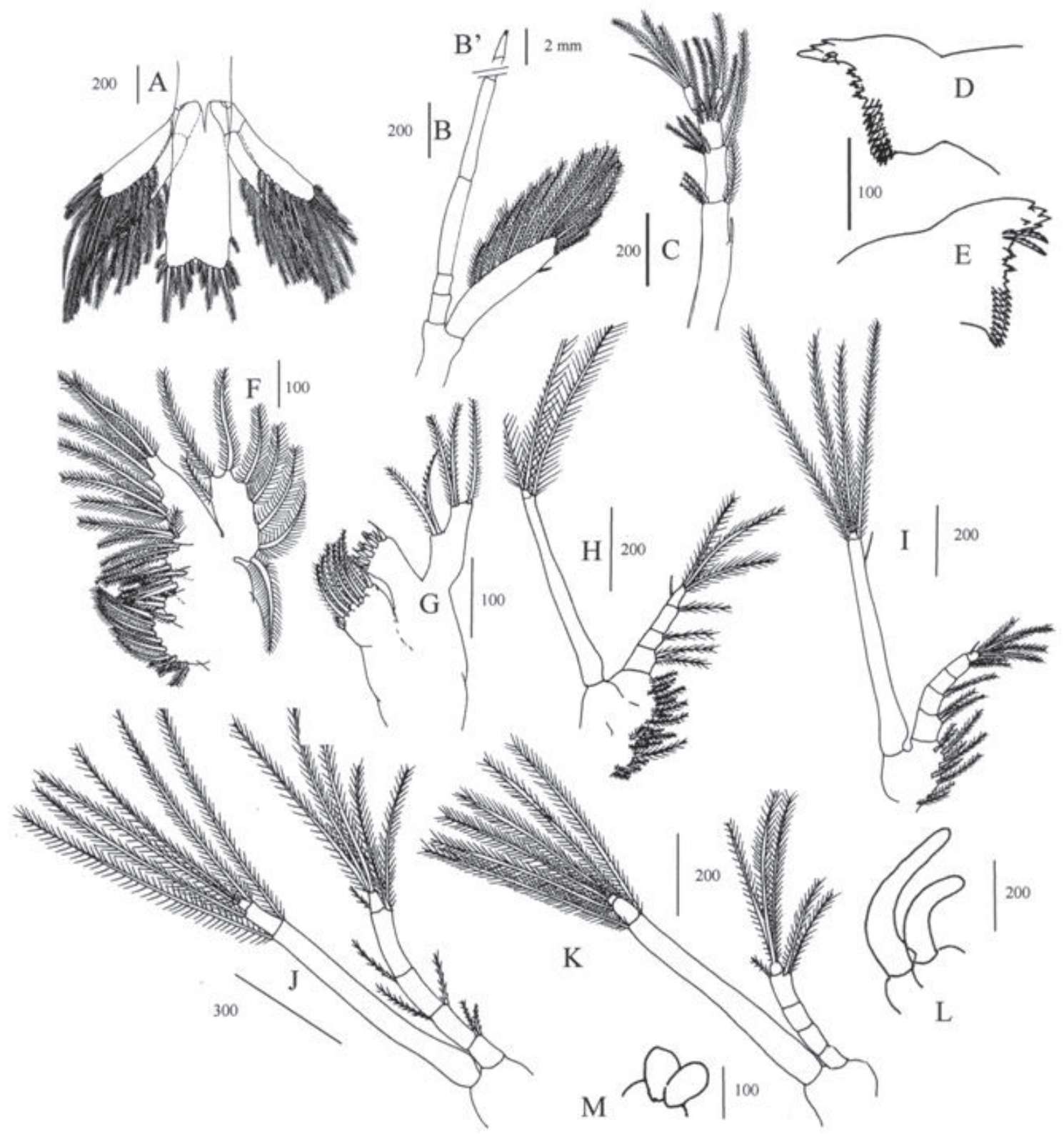

Fig. 5: Rhynchocinetes typus, zoea V. (A) telson, (B) antenna, (B') distal end of the flagellum, (C) antennule, (D) left mandible, $(\mathrm{E})$ right mandible, $(\mathrm{F})$ maxilla, $(\mathrm{G})$ maxillule, $(\mathrm{H})$ first maxilliped, (I) second maxilliped, (J) third maxilliped, (K) first pereiopod, (L) second pereiopod, (M) third pereiopod. Scales in $\mu \mathrm{m}$.

Rhynchocinetes typus, zoea V. (A) telson, (B) antena, (B') extremo distal del flagellum, (C) anténula, (D) mandíbula izquierda, (E) mandíbula derecha, (F) maxila, (G), maxílule (H) primer maxilípedo, (I) segundo maxilípedo, (J) tercer maxilípedo, $(\mathrm{K})$ primer pereiópodo $(\mathrm{L})$ segundo pereiópodo, $(\mathrm{M})$ tercer pereiópodo. Escalas en $\mu \mathrm{m}$. 


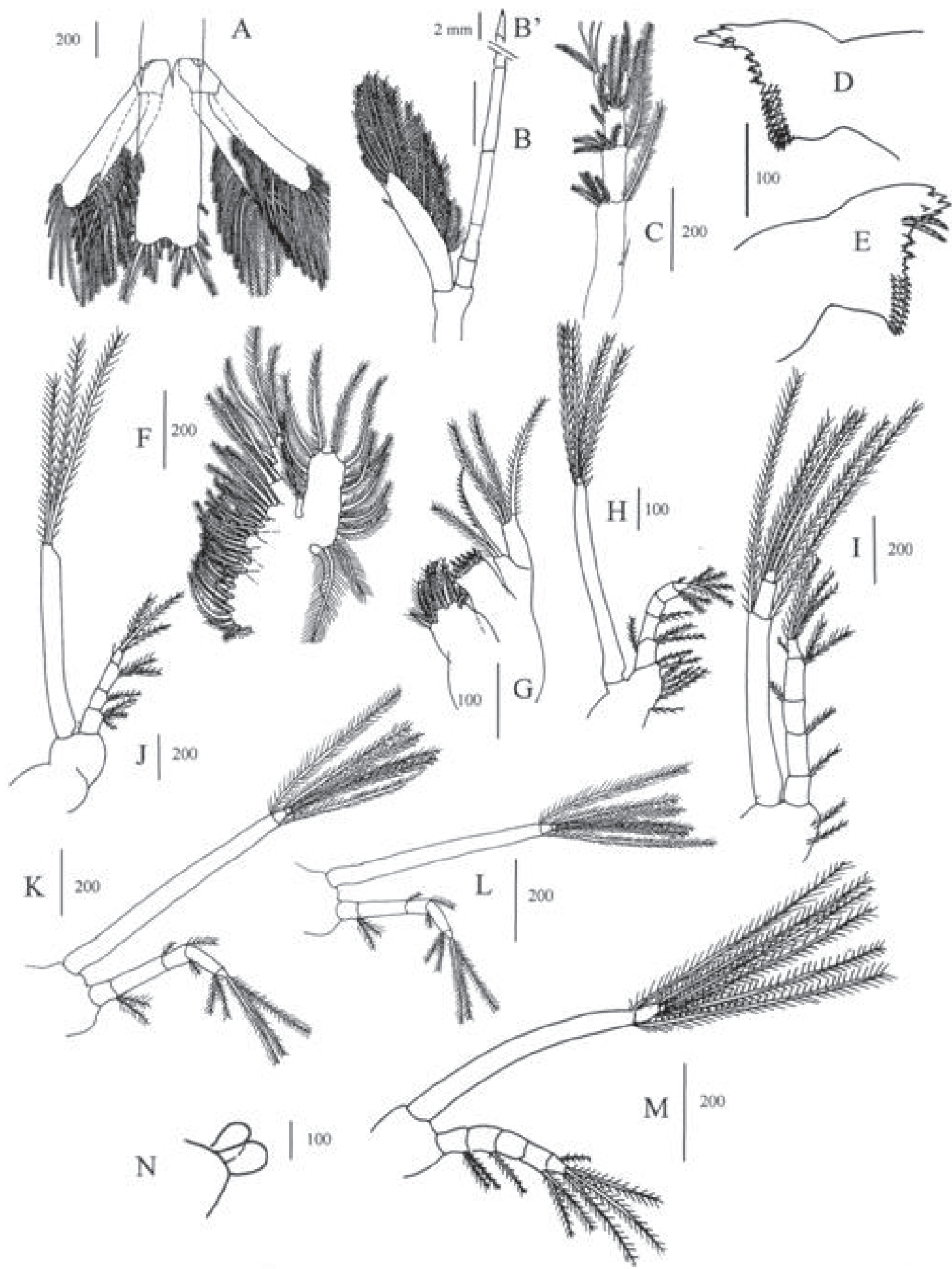

Fig. 6: Rhynchocinetes typus, zoea VI. (A) telson, (B) antenna, (B') distal end of the flagellum, (C) antennule, (D) left mandible, (E) right mandible, $(\mathrm{F})$ maxilla, $(\mathrm{G})$ maxillule, $(\mathrm{H})$ first maxilliped, (I) second maxilliped, $(\mathrm{J})$ third maxilliped, $(\mathrm{K})$ first pereiopod, $(\mathrm{L})$ second pereiopod, $(\mathrm{M})$ third pereiopod, (N) fourth pereiopod. Scales in $\mu \mathrm{m}$.

Rhynchocinetes typus, zoea V. (A) telson, (B) antena, (B') extremo distal del flagellum, (C) anténula, (D) mandíbula izquierda, (E) mandíbula derecha, (F) maxila, (G), maxílule (H) primer maxilípedo, (I) segundo maxilípedo, (J) tercer maxilípedo, (K) primer pereiópodo (L) segundo pereiópodo, $(\mathrm{M})$ tercer pereiópodo, (N) cuarto pereiópodo. Escalas en $\mu \mathrm{m}$. 
Carapace and abdomen. Similar to the preceding stage.

Telson (Fig. 7A). The exopodite of the uropod bears 22-23 setae and the endopodite bears 19 plumose setae. The remainder is the same as in the previous stage.

Antenna (Fig. 7B). The scaphocerite bears 20-21 plumose setae along its entire lateral border.

Antennule (Fig. 7C). Trisegmented. The distal border of the proximal segment is surrounded by 10-13 small semi-plumose setae, and with one thick, long plumose seta on the distal internal border; there is a naked internal spine at its base. The distal border of the middle segment is surrounded by $6-8$ plumose setae, with one thickened plumose seta on its distal internal border. The distal segment has five thick, plumose setae in a ventral, subdistal position and 5-6 small, semi-naked setae at a dorsal, subterminal level. The internal flagellum is similar to zoea III. Some larvae showed a flagellum with a spiral form.

Mandible (Fig. 7D-E). The right mandible remains unchanged; the left has two rows of three tridentate denticles between the molar and incisor. The incisor remains unchanged. There is a triple lacinia movilis.

Maxilla (Fig. 7F). The scaphognathite bears 21-22 plumose setae on its external border.

Maxillule (Fig. 7G). Unchanged.

First maxilliped (Fig. 7H). The exopodite is similar to zoea VI. The basipodite and coxopodite bear 21 and 8-9 plumose setae, respectively.

Second maxilliped (Fig. 7I). Unchanged.

Third maxilliped (Fig. 7J). The endopodite bears 11 setae in the formula $2,1,1,2,4+1$; and the remainder is similar to zoea $\mathrm{V}$.

First pereiopod (Fig. 7K). The exopodite is formed in four segments in the proportion $8: 1$ : $1: 0.5$ and with eight plumose setae in the 2,2 , 2, 2 formula. The endopodite is similar to zoea $\mathrm{V}$. The basipodite and coxopodite bear a total of three plumose setae.

Second, third and four pereiopods (Fig. 7LN). Unchanged.

Five pereiopod (Fig. 7N). The endopodite and exopodite are rudimentary.
Rhynchocinetes typus is the first species of the Rhynchocinetidae family, belonging to Caridea Infraorder, from the South America coast whose larval development is described therefore the comparison with other congeneric sympatric species, was not possible. It was only possible the comparison with species from Japan and Corea coast (Motoba \& Shokita 1998, Maihara \& Kyoya 2001a, Maihara 2002). The present study is the second complete description of the larval development of 46 Caridean species from Chile.

The sequence of seven developmental larval stages of $R$. typus follows a general pattern similar to other carideans cultured in the laboratory (Gurney 1942, Chong \& Khoo 1987, Komai \& Mizushima 1993, Wong 1989, 1994, Pereira \& García 1995, Albornoz \& Wehrtmann 1997) and specifically in the Rhynchocinetids species. But R. typus differs from the others Rhynchocinetids in having only 7 stages of development in contrast with $R$. uritani (Maihara 2002) which have 10 stages, $R$. conspiciocellus which has 11 stages (Motoba \& Shokita 1998), C. striatus with 11 stages (Maihara \& Kyoya 2001a), $C$. hendersoni with 11 stages and $R$. rigens with 10 stages (Gurney 1942). There are some Caridean species with only three larval stages such as in Macrobrachium malayanum (Chong \& Khoo 1987) and Pandalopsis japonica (Komai \& Mizushima 1993) but most of the carideans have more than five stages (Gurney 1942, Knowlton 1974, Wong 1989, 1994, Pereira \& García 1995, Wehrtmann \& Albornoz 1997), similarly to $R$. typus. When we compare the stage number reported for other Rhynchocinetidae, $R$. uritani (Maihara 2002) and $R$. conspiciocellus (Matoba \& Shokita 1998) all of them are over 7 stages but in all of them the presence of pleopods on the abdomen was reported. This characteristic were not observed in any of the cultures after reaching the stage VII zoea; at this stage the individuals continued moulting and growing without producing morphological changes as pleopod buds on the abdomen. Anger (personal communication) has showed that the first manifestation of metamorphose imply the appearance of pleopods. 


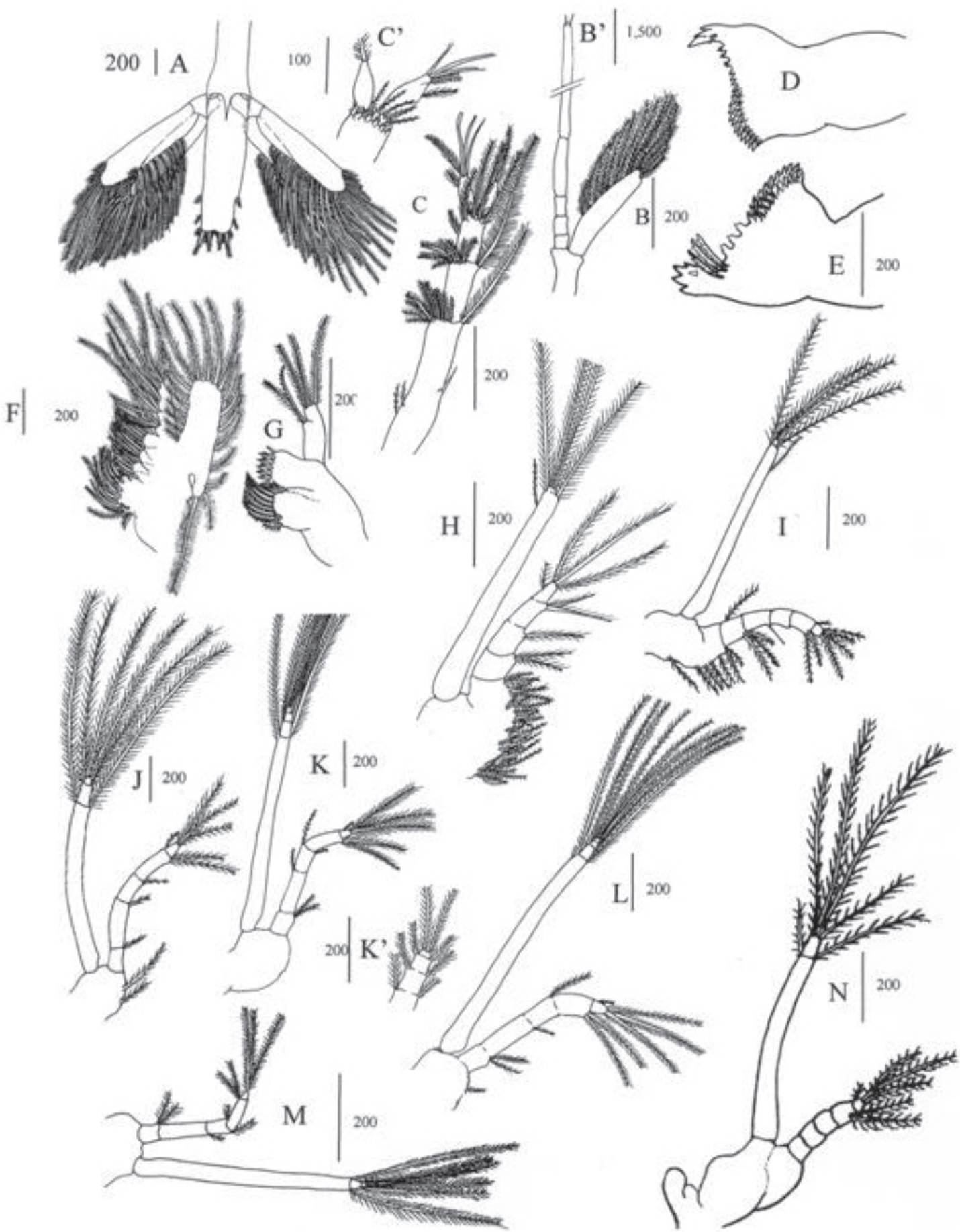

Fig. 7: Rhynchocinetes typus, zoea VII. (A) telson, (B) antenna, (B') distal end of the flagellum, (C) antennule, $\left(C^{\prime}\right)$ distal end of the antennule, (D) left mandible, (E) right mandible, $(\mathrm{F})$ maxilla, (G) maxillule, (H) first maxilliped, (I) second maxilliped, (J) third maxilliped, (K) first pereiopod, (K') distal end of the exopod of the first pereiopod, (L) second pereiopod, (M) third pereiopod, (N) fourth pereiopod with the bud of the fifth pereiopod. Scales in $\mu \mathrm{m}$.

Rhynchocinetes typus, zoea V. (A) telson, (B) antena, (B') extremo distal del flagellum, (C) anténula, (C') extremo distal de la anténula, (D) mandíbula izquierda, (E) mandíbula derecha, (F) maxila, (G), maxílule (H) primer maxilípedo, (I) segundo maxilípedo, (J) tercer maxilípedo, $(\mathrm{K})$ primer pereiópodo, $\left(\mathrm{K}^{\prime}\right)$ extremo distal del exópodito del primer pereiópodo, (L) segundo pereiópodo, $(\mathrm{M})$ tercer pereiópodo, (N) cuarto pereiópodo con rudimento del quinto pereiópodo. Escalas en $\mu \mathrm{m}$. 
Major changes in the form of the cephalothorax were not observed during the larval development of $R$. typus. The sessile eyes of the zoea I stage became pedunculate in the zoea II stage. The abdomen retained six segments throughout larval development, in contrast with Albornoz \& Wehrtmann (1997) who only reported five segments. The latter observation may, however, have been due to the fact that the sixth abdominal segment is fused to the telson in the first zoeal stage, a condition lost in the second zoeal stage, and beyond.

Among the cephalic appendages of R.typus, the antennae undergo the most morphological change during larval culture. The scaphognathite from zoea I to zoea III has six segments and a cylindrical aspect, similar to $R$. rigens (Gurney 1942) and $R$. uritani (Maihara 2002), C. striatus (Maihara \& Kyoya 2001a) and C. hendersoni (Maihara \& Kyoya 2001b). Beginning with zoea IV the six segments of the scaphognathite become fused and take on a laminar asegmented form. From zoea IV the flagellum of the antenna is bisegmented and increases in total length and number of segments until zoea VII which has 15-20segments. The same development was reported by Gurney (1942) for $R$. rigens, for $R$. uritani (Maihara 2002) and C. striatus (Maihara \& Kyoya 2001a), but in $C$. hendersoni the fusion it produce at zoea III (Maihara \& Kyoya 2001b). In R. typus, some larvae past the stage $\mathrm{V}$ zoea were occasionally observed which did not possess an elongated flagellum, but rather a spiral flagellum; this observation has not been reported for any other species in the genus Rhynchocinetes.

The maxillulae maintain a stable morphology until reaching stage IV, presenting a small exopodite with two plumose setae. This condition differs from $R$. rigens which bears an exopodite with three plumose setae (Gurney 1942) as occur in R. uritani (Maihara 2002) and C. striatus (Maihara \& Kyoya 2001a) too. This exopodite disappears from $R$. typus in the stage $\mathrm{V}$ zoea and in stage $\mathrm{V}$ and $\mathrm{VI}$ in $C$. striatus (Maihara \& Kyoya 2001a) and R. uritani (Maihara 2002) respectively.

The morphology of the telson changes during larval development from triangular and bilobed, to rectangular, elongated, and narrow. The occurrence of seven spines on each lobe of the telson of the $R$. typus zoea I was different from the six spines reported for each lobe in $R$. rigens (Gurney 1942). The outlines of the future uropods could be noted on the interior of the telson of zoea II, although actual uropods were not yet present at this stage. These outlines were particularly notable a few days prior to change of stage of the zoea II larva. Uropods were present beginning in the stage III zoea, and increased in their numbers of plumose setae both on the endopodites and exopodites. However this structure can not considered distinguishing between Rhynchocinetids species because they are very similar in each stage of $R$. typus, $R$. uritani, $C$. striatus and $C$. hendersoni (Maihara \& Kyoya 2001a, 2001b).

The pereiopods are useful indicators of the zoeal stage in $R$. typus, as new pereiopod pairs appear in each new stage from zoea II through zoea VII. This is in contrast with Albornoz \& Wehrtmann (1997), who reported the appearance of the first pair of pereiopods in $R$. typus in zoea I. The appearance of developed pereipods in $R$. rigens was reported as first occurring in the stage VIII zoea (Gurney 1942), in $R$. uritani the first pereiopod appears in the third zoea (Maihara 2002), in $C$. striatus and $C$. hendersoni it appears in the second zoea (Maihara \& Kyoya 2001a, 2001b).

The identification of the larval stage in $R$. typus can be made by observing the characteristics of four main structures including the telson, uropods, antennae, and pereiopods. The morphology of the telson is the most convenient indicator of the larval stage from the first stage (zoea I) to zoea IV. In the first stage there are only seven setae on each lobe of the telson and no uropods; this number of setae increases to eight per lobe in zoea II. The uropods appear in zoea III, with six setae on the exopodite and two on the endopodite; in zoea IV these setal numbers change to 12 on the exopodite and six on the endopodite. From here onward, the telson begins to lose its triangular shape, becoming rectangular (zoea $\mathrm{V}$ ) and the numbers of the setae on the endopodites and exopodites of the uropods increase.

It is worth noticing that pleopods are shown in the seven stage in R. uritani (Maihara 2002) but in $R$. typus, after the seven stage the larvae continue the moults (3-5 times) increasing the 
total length but never changed to other stage and pleopods were never observed.

Finally, the insights on larval morphology obtained in the current study gives is critical to facilitate the identification of this species for further studies dealing with revealing the temporal and spatial patterns in the early life stages of this species, one of the most important commercial crustacean in the smallscale fisheries in Chilean waters.

\section{ACKNOWLEDGEMENTS}

This study was supported by Project 194-1121 Fondo Nacional de Ciencia y Tecnología (CONICYT) to Prof. E. Dupré and project DGICT-UCN

\section{LITERATURE CITED}

ALBORNOZ L \& I WEHRTMANN (1997) Descripción y clave de los primeros estadios de camarones carídeos (Decapoda: Hippolytidae, Alpheidae; Rhynchocinetidae) de aguas costeras de Chile. Investigaciones Marinas (Chile) 25: 121-133.

BÁEZ P (1997) Key to families of decapods crustacean larvae collected off northern Chile during an El Niño event. Investigaciones Marinas (Chile) 25: 167-176.

BAHAMONDE N \& M LÓPEZ (1967) Notas sobre el camarón Rhynchocinetes typus (Milne Edwards, 1837). Boletín Museo de Historia Natural (Chile) 29: 121-227.

CHONG S \& H KHOO (1987) The abbreviated larval development of the freshwater prawn, Macrobrachium malayanum (Roux 1934) (Decapoda, Palaemonidae), reared in the laboratory. Crustaceana 53: 29-42.

CRIALES M \& K ANGER (1986) Experimental studies on the larval development of the shrimps Crangon crangon and C. allmanni. Helgoländer Meeresuntersuchungen 40: 241-265.

DISALVO L, J RANDALL \& A CEA (1988) Ecological reconnaissance of the Easter Island sublittoral marine environment. National Geographic Research (USA) 4: 451-473.

DUPRÉ E, G BELLOLIO \& K LOHRMANN (1992) Cultivo del camarón de roca Rhynchocinetes typus. Desarrollo embrionario y larval. Informe Final Convenio Cidere IV Región-Universidad Católica del Norte, Chile. 45 pp.

HARTNOLL R (1982) Growth. In: Bliss D (ed) The biology of crustacea 2: 111-197. Academic Press, London, United Kingdom.

GURNEY R (1942) Larvae of decapod crustacea. The Ray Society of London Publisher, London, United Kingdom. 306 pp.

KNOWLTON R (1974) Larval development processes and controlling factors in decapoda Crustacea, with emphasis on Caridea. Thalassia Jugoslavica 10: 139-158.
KOMAI T \& T MIZUSHIMA (1993) Advanced larval development of Pandalopsis japonica Balss, 1914 (Decapoda, Caridea, Pandalidae) reared in the laboratory. Crustaceana 64: 24-39.

MAHIARA Y (2002) Larval stages of the Rhynchocinetid shrimp, Rhynchocinetes uritani Kubo, 1942 (Decapoda, Caridea, Rhynchocinetidae). Scientific Report of Museum of Tokai University 4: 59-77.

MAHIARA Y \& N KYOYA (2001a) Larval stages of the Rhynchocinetid shrip, Cinetorhynchus striatus (Nomura \& Hayashi, 1992) reared in laboratory. Scientific Report of Museum of Tokai University 3: 43-62.

MAHIARA Y \& N KYOYA (2001b) Larval stages of the Rhynchocinetid shrimp, Cinetorhynchus hendersoni (Kemp, 1925) (Decapoda, Caridea, Rhynchocinetidae) reared in laboratory. Bulletin of Institute Oceanic Research and Development, Tokai University 22: 75-91.

MASCETTI P \& I WEHRTMANN (1996) Aspects of the reproductive biology of Petrolisthes laevigatus (Guérin, 1835) (Decapoda, Anomura, Porcellanidae). Part III: Efects of starvation and different types of diet on larval development under laboratory conditions. Archive of Fishery and Marine Research 43: 159-170.

MIRANDA O \& M KONG (1970) El camarón de mar en Antofagasta (Rhynchocinetes typus, Milne Edwards, 1837). Crustacea, Decapoda, Rhynchocinetidae. Biología Pesquera (Chile) 4: 41-63.

MOTOBA H \& S SHOKITA (1998) Larval development of the Rhynchocinetid shrimp, Rhynchocinetes conspiciocellus Okuno \& Takeda (Decapoda, Caridea, Rhynchocinetidae) reared under laboratory conditions. Crustacea Research 27: 40-69.

MUJICA A (1993) Zooplancton en las aguas que circundan a Isla de Pascua. Ciencia y Tecnología del Mar (Chile) 16: 55-61.

NUMURA K \& K HAYASHI (1992) Rhynchocinetes striatus, a new species (Decapoda, Caridea, Rhynchocinetidae) from southern Japan. Zoological Science 9: 199-206.

PALMA S (1976) Meroplancton de la región de Valparaíso. Ciencia y Tecnología del Mar (Chile) 2: 99-116.

PALMA S (1980) Larvas de crustáceos decápodos capturados frente a la costa de Valparaíso. Investigaciones Marinas (Chile) 8: 129-144.

PEREIRA G \& J GARCÍA (1995) Larval development of Macrobrachium reyesi Pereira (Decapoda: Palaemonidae), with a discussion on the origin of abbreviated development in Palaemonids. Journal of Crustacean Biology 15: 117-133.

PHILLIPS B \& P MCWILLIAMS (1986) The pelagic phase of spiny lobster development. Canadian Journal of Fishery and Aquatic Science 43: 2153-2163.

RETAMAL M (2000) (CD-ROM) Decápodos de Chile. World Database Biodiversity. ETI-Universidad de Concepción. Springer-Verlag, Berlin, Germany.

SERIDJI R (1986) Larves de crustacés décapodes des eaux jordaniennes du golfe d'Aqaba. Note préliminaire. Vie Marine 7: 1-13.

SCHULTZE K \& K ANGER (1997) Larval growth patterns in the aesop shrimp Pandalus montagui. Journal of Crustacean Biology 17: 427-479.

VÁSQUEZ J \& JC CASTILLA (1982) Áreas de reclutamiento y estructura poblacional de Rhynchocinetes typus Milne Edwards, 1837 (Crustacea, Rhynchocinetidae). Investigaciones Marinas (Chile) 1: 1-14. 
WALSH C (1993) Larval development of Paratya australiensis Kemp, 1917 (Decapoda: Caridea: Atyidae), reared in the Laboratory, with compare of fecundity and egg and larval size between estuarine and riverine environments. Journal of Crustacean Biology 13: 456-480

WEHRTMANN I \& L ALBORNOZ (1997) Larval Development of Nauticaris magellanica (A. Milne Edwards, 1891) (Decapoda: Caridea: Hippolytidae), reared under laboratory conditions. Bulletin of Marine Science 60: 1-46.

WILLIAMS B (1968) Laboratory rearing of the larval stages of Carcinus maenas (L.) (Crustacea: Decapoda). Journal of Natural History 2: 121-126.

WILLIAMSON D (1969) Names of the larvae in the Decapoda and Euphausiacea. Crustaceana 16: 210-213.

WONG J (1989) Abbreviated larval development of Macrobrachium hainanense (Parisi, 1919) reared in the laboratory (Decapoda, Caridea, Palaemonidae). Crustaceana, 56: 18-30.

WONG J (1994) Larval development of the Palaemonid prawn, Macrobrachium lanchesteri (de Man) reared in the laboratory (Decapoda, Caridea). Crustaceana 67: 297-315.

Associate Editor: Sergio Navarrete

Received June 8, 2007; accepted August 14, 2007 